Actes de l'atelier Langue de spécialité du 33 e congrès de la SAES

\title{
Writing scientific articles in English: Solutions for French researchers?
}

\section{Susan Birch-Bécaas}

\section{(2) OpenEdition}

\section{Journals}

Electronic version

URL: http://journals.openedition.org/asp/4234

DOI: $10.4000 /$ asp.4234

ISSN: 2108-6354

\section{Publisher}

Groupe d'étude et de recherche en anglais de spécialité

\section{Printed version}

Date of publication: 1 February 1994

Number of pages: $57-64$

ISSN: 1246-8185

\section{Electronic reference}

Susan Birch-Bécaas, « Writing scientific articles in English: Solutions for French researchers? », ASp [Online], 3 | 1994, Online since 20 February 2014, connection on 19 April 2019. URL : http:// journals.openedition.org/asp/4234; DOI : 10.4000/asp.4234

This text was automatically generated on 19 April 2019

Tous droits réservés 


\title{
Writing scientific articles in English: Solutions for French researchers?
}

\author{
Susan Birch-Bécaas
}

1 For some time now, the international scientific community has been witnessing the increasing prevalence of the English language in its publications and communications. The United States have become a pole for scientific information, giving rise to the most prestigious journals. Thus it has become imperative for French scientists and researchers to publish in English if their voices are to be heard on an international scale. However the non-native speaker (NNS) may often be at a disadvantage in this obstacle race which is the road to publication.

2 The Research Article (RA) leaves the NNS wide open to criticism from reviewers and editors as he is reporting both new and possibly controversial findings, and is doing so in a second language. The NNS must follow precise rules if his article is to be accepted by the scientific community and although the decision of reviewers may be based essentially on the content, the accuracy of grammar, vocabulary, spelling and punctuation is still important if the article is not to be rejected for "poor English".

3 In an effort to help NNS overcome obstacles to publication, various studies have been carried out. In the 1960s, Barber (1962) and Herbert (1965) analysed the characteristics of scientific English and such quantitative studies of the structure of the target language have been used for syllabus design. In the 1970s the focus was placed on the rhetorical functions of language, and the communicative character of the text and discourse analysis is now used to describe the conventions of scientific texts, and to establish learner needs. As Widdowson says,

Scientific exposition is structured according to certain patterns of rhetorical organisation which, with some tolerance for individual stylistic variation, imposes a conformity on members of the scientific community no matter what language they happen to use. (as quoted in Swales 1990: 65)

The work of Swales on article introductions and that of Hopkins and Dudley-Evans on the discussion section reveal the internal patterning of the text, and the link between the 
author's purpose and linguistic choice. However, while much of the research has been concerned with undergraduate writing, there is a need for further investigation to help researchers. As Hopkins and Dudley-Evans claim,

Far more work needs to be done in order to build up a solid stock of information about the structure of various genres and subgenres and to develop our knowledge of regularities and varieties of textualisation associated with particular moves and particular move cycles within identifiable groups of texts. (Hopkins \& Dudley-Evans 1988: 120)

5 However, the fully-fledged researcher has gradually become accustomed to scientific narrative and its structure by reading many such articles. Through the reading of model texts the researcher finds no great difficulty in organising his article. He is aware of the different rhetorical functions of the various sections of the article and in some cases of the linguistic requirements of each section. Philip Shaw in a study with overseas postgraduate students found that, "by far the most frequent strategy used by these interviewees to improve their command of the subject register was conscious examination of their source texts" (Shaw 1991: 195). The problem remains though that these typical forms of language still cause difficulty. Whatever the discipline, whatever the paper, errors of article, tense, and modal loom large.

6 For these reasons I have chosen to look purely and simply at the language errors which occur and the frequency with which they occur. For if we can identify persistent errors in texts, this should be of help to both scientist and corrector in the production of articles. To my mind researchers are not wanting in the realms of structure, organisation or rhetorical function but they do need guidance on what to use, when and how. Their attention needs to be drawn to their persistent errors and then they will be part way to eliminating them. Christine Pearson Casanave and Philip Hubbard have shown in a study of doctoral students that the differences between NNS and NS

were the greatest in the areas of correctness of punctuation, spelling, accuracy of grammar, appropriateness of grammar and appropriateness of vocabulary, the differences were the smallest at the discourse level. (Pearson Casanave \& Hubbard 1992: 38)

7 Surely then it is in this area that NNS need help if they are to compete with Anglophone counterparts. Furthermore Christine Pearson Casanave believes that problems "involving articles, prepositions and tense persist over time and across proficiency levels" (Pearson Casanave \& Hubbard 1992: 44).

8 For this study a corpus of 50 research articles was selected. They were chosen for their typical structure, that is the Introduction, Methods, Results, Discussion pattern, and their typical length, in order to focus on the linguistic features. All the RAs were written by French native speaker researchers who had chosen to use the correction services of our language department. What is of interest of course is not the published article but the first draft, written by the researchers and then submitted for correction. As our language department is attached to the faculty of medicine and life sciences, these subjects do predominate, but the fields vary from biochemistry, cancer research, cardiology, psychology to oenology. Such a varied corpus should make it possible to see if the same sorts of mistakes are being made not only as Christine Pearson Casanave says, "across proficiency levels" but also "across the board".

9 The first step of my study has been to conduct structured interviews with the authors of the texts. I have thus been able to complete my corpus with various drafts and versions of 
each text. The authors are therefore able to describe the difficulties they encounter with their first drafts and the type of assistance they require. The use of specialist informants is important to study their conscious learning strategies, their composing processes and how they acquire their genre knowledge.

First of all it needs to be underlined that medical doctors and researchers have very little time to devote to improving their English. Unlike post-graduate students their English studies are often a distant glimmer in the past. In fact for some of the older researchers interviewed, their last English course was that followed at secondary school and their years of higher education were completely void of English. Some of the more determined researchers have followed courses in our department, but since such courses are sponsored by the CNRS or INSERM and as many members of the lab would like to attend at some point, their 'turn' might come around only once every 10 years or so.

11 Of course there are researchers who have spent time in the United States; but as some claim, although they may now feel at ease with everyday conversation they still have difficulty in writing up their research. It is important to emphasise that the interest in English is there, revived by the constant necessity of reading articles in English and the desire not just to publish a paper but to be able to express fully their findings and the implications of these findings. Reading comprehension skills are gradually acquired but assistance is necessary for the preparation of written and oral communications.

rearchers who have requested assistance with the writing of articles, now, on the advice of our department, opt to write their articles directly in English and then to consult with a corrector. The researchers read in English and at times may think in English so it is all the more natural to write in English. In the past some have made translations of French first versions, often with the help of Anglophone colleagues in their lab, but they find translating to be difficult as although French research articles may follow the same format, they believe that the language used is very different. As one researcher put it, English is more concise and 'brutal' whereas in French the whole way of thinking and constructing ideas is different, and it is difficult to translate this language of nuances. Odile Régent has described the cultural differences between French medical texts and English ones,

L'article français est plus centré sur les faits, l'anglais sur une argumentation; le paragraphe français est fragmenté par de nombreux alinéas qui divisent le thème en sous-thèmes. Le paragraphe anglais est plus compact. Les assertions en anglais destinées à convaincre après avoir informé sont beaucoup plus fortes qu'en français où on se contente souvent d'informer. Le passé est toujours utilisé en anglais pour la description des faits, tandis que le français emploie le présent qui donne à la description un aspect intemporel. (quoted in Causse 1983: 173)

13 A researcher may have recourse to the services of a professional translator, but unless the latter is a subject specialist there is a danger that the translation will end in loss of meaning.

Thus the researchers set about writing their text in English. This may follow from a careful plan, discussion with other researchers and often a number of drafts are made before meeting with the corrector. It is at this point that their study of other articles becomes invaluable. As they are familiar with the predictable pattern of the article they tend to rely on this structure, using the various articles of their bibliography to enhance their knowledge of English, picking out expressions from model texts, using conjunctions, a process which enables the authors to form the framework of their text and avoid too 
much interference from Language 1 . Some interviewees said that as they read texts they made notes of useful phrases and expressions. Philip Shaw too has found that

critical imitation of models and collection of subject-specific lists of words and phrases are forms of awareness-raising within this process, which help learners to assimilate the conventions of the genre and the register of their subject. (Shaw 1991: 199)

All researchers clearly state that their problem lies not in the specialised terminology of their field but rather in the sub-technical vocabulary. Thus the 'typical' expressions and turns of phrase that they need, which can quite often be lifted from other articles, may not vary greatly from field to field. Therefore a collection of such useful expressions could be a useful tool for the researcher. Annette Kazes clearly expresses what other ESP practitioners may feel in stating that

the profound difficulties about ESP lie, not in the specific terminology attached to it, but in the English language itself, in its syntax, grammar and in the complexity of its vocabulary. (Kazès 1993: 262)

Since much of the difficulty lies neither in organising the text nor in the vocabulary required, it becomes clearer where the real problems may be experienced.

Some sections of the article seem easier to write such as the factual "methods" and "results". Researchers claimed to have more difficulty with the "introduction" and the "discussion" as their vocabulary is limited, and it is here that other texts intrinsically provide less support. Most authors seem capable of recognising their persistent errors but the latter may recur throughout a text and from one text to the next, as they are not pinpointed and revised accordingly. In fact the only time they may be studied is during the revision session with the corrector, help which most researchers found invaluable and classed as time well-spent. The researchers seem to have problems in the same areas and so there emerges a common-core of problem areas, across the different disciplines (whether these mistakes are common to researchers of different linguistic backgrounds remains to be seen). These recurrent errors need to be exploited. Although the researchers are often capable of identifying these persistent errors, little progress may be made as they are not seen from one paper to another. In order to improve researchers' writing skills and to save both researcher and corrector time, a set of tools needs to be developed which provides help with these basic but problematic errors and which could be used as a reference guide for researchers. The form and contents of these tools will become clearer as a full error analysis is made of the corpus.

Further study of scientific texts should be of great use to researchers. In some genres, sentence-level phenomena may not be so important and may not lead to a breakdown in communication, but for the RA, accuracy and clarity are of the utmost importance and work is undoubtedly needed in these areas. 


\section{BIBLIOGRAPHY}

Barber, C.L. 1962. "Some measurable characteristics of scientific prose". In Contributions to English Syntax and Phonology. Stockholm: Almquist and Wiksell, 1-23.

Causse, Françoise. 1983. "Problématique d'une formation à la rédaction scientifique en anglais". In Perrin, M. (ed.), Actes du 4 e Symposium Européen sur les langues de spécialité, Pratiques d'aujourd'hui et besoins de demain. Bordeaux: Université Bordeaux 2, 169-177.

Herbert, A.J. 1965. The Structure of Technical English. London: Longman.

Hopkins, A. \& Dudley-Evans, T. 1988. "A genre-based investigation of the discussion sections in articles and dissertations”. English for Specific Purposes 7, 113-121.

Kazes, Annette. 1993. “Cours d'anglais pour paradontologistes”. ASp 1, 251-277.

Pearson Casanave, C. \& Hubbard, P. 1992. "The writing assignments and writing problems of doctoral students: Faculty perceptions, pedagogical issues and needed research". English for Specific Purposes 11, 39-49.

Shaw, P.1991. “Science research students' composing processes". English for Specific Purposes 10, 189-206.

Swales, J. 1990. Genre Analysis. Cambridge: Cambridge University Press.

\section{Selected bibliography}

Cooke, Ray. 1993. "Learning to publish in English: How can French researchers bridge the gap?". ASp 1, 463-474.

Jaudel, P. 1982. "Collaboration de l'angliciste et de chercheurs en médecine dans la rédaction d'un article scientifique". Actes $d u V^{e}$ Colloque du GERAS, Montpellier,19-21.

Krashen, S.D. 1981. Second Language Acquisition and Second Language Learning. London: Pergamon Press Ltd.

Parkhurst, C. 1991. “The composition process of science writers”. English for Specific Purposes 10, 189-206.

St John, M. 1987. "Writing processes of Spanish scientists publishing in English". English for Specific Purposes 6, 113-120.

Swales, J. 1988. Episodes in ESP - A source and reference book on the development of English for Science and Technology. New York: Prentice Hall.

Trimble, L.1985. English for Science and Technology. Cambridge: Cambridge University Press.

Vidalenc, J. L. 1993. “Un apport de l'analyse du discours à l'apprentissage de la rédaction d'articles scientifiques : l'étude des phénomènes de connexion”. ASp 1, 383-401.

\section{ABSTRACTS}

Work already carried out on the structure of scientific narrative has revealed the regularities and the internal patterning of such texts and it is interesting to see how this genre knowledge is 
acquired by the authors. Interviews with specialist informants give us an insight into their composing processes and learning strategies. Furthermore a study of a corpus of research articles should make it possible to identify persistent errors within the texts and to establish a core of problematic grammatical elements. This material can be exploited in order to improve not only the researcher's English but also the collaboration of Anglophone corrector and scientist in the drafting of articles.

Des recherches ont déjà porté sur les caractéristiques linguistiques et discursives de 1 anglais scientifique, montrant les choix grammaticaux et le schéma interne des textes. Une enquête auprès d'auteurs nous permet d'étudier leurs stratégies d'apprentissage de la langue et des conventions du discours ainsi que leur façon de rédiger. De plus, une étude d'un corpus d'articles scientifiques devrait révéler les erreurs récurrentes qui forment le noyau d'éléments problématiques. Ces données devraient permettre le développement d'un outil pédagogique. Ce dernier répondrait aux besoins des chercheurs et améliorerait la collaboration entre le correcteur anglophone et le chercheur, pour faciliter le passage de celui-ci à la communication internationale.

INDEX

Keywords: composing process, corrector, error, scientific journal article, researcher

Mots-clés: article de revue scientifique, chercheur, correcteur, erreur, stratégie de rédaction

\section{AUTHOR}

\section{SUSAN BIRCH-BÉCAAS}

Département des langues vivantes pratiques (DLVP), Université Bordeaux 2. susan.birch@ubordeaux2.fr 